\title{
The Pattern of Intragroup Conflict and Group Performance during Interprofessional Teamwork Process among Students of Medical and Health Professionals
}

\author{
Dwi Tyastuti, Devy Ariany, Alfiah \\ Faculty of Medicine and Health Sciences \\ Syarif Hidayatullah State Islamic University \\ Jakarta, Indonesia \\ dwityastuti@uinjkt.ac.id
}

\begin{abstract}
Teamwork and collaborative practice are necessary tools in handling health problems and the importance of interprofessional teamwork is becoming increasingly recognized. The process of team development is a series of multilevel, overlapping responsibilities, which are intertwined with each other, and disruption of team development process will lead to conflict. This study analyzed the pattern of intragroup conflict and group process in an interprofessional team. The study was conducted at the State Islamic University (UIN), Jakarta, Indonesia from February to October 2012 and involved 62 students (77.5\% of total sample) from four disciplines (medicine, nursing, pharmacist and public health). They engaged in an interprofessional learning for community-based health care (COMIC program). Following their participation in this program, a positive result was achieved of improved group process (factors of trust, mutual respect, and open discussion) with significant statistical impact on the improvement of intragroup conflict (conflict of relationship, task and process) over time. This research produced a unique pattern of intragroup conflict and group process for each discipline.
\end{abstract}

Keywords- intragroup conflict; group performance; interprofessional teamwork; collaborative practice

\section{INTRODUCTION}

An effective team will be able to achieve the set goal by working effective in teamwork [1]. However, working in a team is not a simple task, especially when working in groups or with different profession backgrounds that never exposed. Working effectively in team are considerable challenges and one of this is conflict. Conflict is the process resulting the tension between team members because of real perceived differences [2,3]. However, team conflict in itself can be a process of initiation and outcome of individual interactions [4]. In management organization, conflicts within a team are the resources that must be managed to be team strength [1-3]. In interprofessional learning, conflict can emerge from interaction among individual professions during the teamwork process $[4,5]$.

Interprofessional education (IPE) is a learning concept that occurs when two or more professions learn with, from and about each other to improve collaboration and the quality of care [6]. To learn from each other, collaborative learning should be implied [7] and students/professions must be exposured in a teamwork. However, IPE program to develop an effective collaboration among undergraduate students is a challenge [8]. How can this learning model develop a team that has a good performance and ability to perform collaborative practice in completing several of tasks are a longitudinal process and it requires an interprofessional team process [4]. The intergroup conflict arose from relation among members between two different groups [2] and intragroup conflict was emerged from interaction among members within a group [1].

To become an effective team, each team undergo the group development process (such as Tuckman's process) [9]. As it is known that the process of formation and development of a team in interprofessional learning is a simultaneously process in one time and not through the phasing process $[4,10]$. Likewise, the process of team development is a series of multilevel, overlapping and intertwined with each other [4]. The interaction between members, interpersonal skills, and group task are the factors that can affects team process and the good team environments will speed up interaction and open communication between members, stimulate the ideas, and configure an ability be an effective team member in an interprofessional team which are currently very important and needed [11]. The insufficient and discrepancies of those factors lead to a conflict within a team [12]

Research on team performance and conflict thrive on non-health organizations or institutions. The research analyzed how the health team performance in application of collaborative practice on IPL have a tremendous opportunity to be explored further. In 2012, UIN Jakarta develop the Community-based Interprofessional Collaboration (COMIC) project as a pilot program that focuses on learning to promote IPE and collaboration practice in Indonesia. The educational program attempted to combine the development of knowledge, attitude, and skills into practice to obtain a complete and comprehensive understanding about interprofessional and collaborative practice among students and tutors at UIN Jakarta. The program provided the opportunity for medicine 
and health professional's students to have hands-on experience of collaborative practice in the community through home care services.

This paper discuss the intragroup conflict (including the conflict of relationship, task and process) and group atmosphere (including relationship, mutual respect and open discussion) and analyzed the relationship both of them during interprofessional learning in COMIC program.

\section{Methodology}

\section{A. Intervention Model}

The intervention consisted of three phases. First was development of knowledge and attitude for IPE. A set of tutorials (communication, empathy, professionalism, socialculture adaptation, team process, and roles of professions) was delivered by applying interactive learning, ice-breaking activity and work in small group. Second, establishment of skills to interact with other profession and to work in team were performed by employing simulation models (Fig.1). The simulation used a model of home care service in Indonesia and involved lecturer as IPE's tutor and community members as standardized patients (SP`s) that both lecturer and community members were trained in two day's workshop.

\section{B. Instrument}

Psychometric analysis and validating of scales

This study used a group atmosphere scale $[12,13]$ and intragroup conflict scale [14] to measure the conflict in group and group development and this scales had the good reliability and validity $[14,10]$. In this study, the scale was adapted in Indonesian language by applying cross-cultural adaptation process [15] to produce a valid and reliable scale that similar to the original version. Those instruments have adopted in Indonesian version (D.Tyasuti).

The group atmosphere (GA) scale was made of eight positive statements and intragroup conflict (IC) consisted of 11 negative statements. Participants were asked to indicate their strength of agreement on a 7-pointLikert-type scale (1=very strongly disagree, $4=$ neutral, $7=$ very strongly agree). The survey was done on $20^{\text {th }}$ to $28^{\text {th }}$ February 2011 among 302 participants of first and third-year students.

\section{Sample/participants}

The sample was drawn from a population of third-year students at Faculty of Medicine and Health Sciences (FHMS), Syarif Hidayatullah State Islamic University (UIN Jakarta), Indonesia and involved 80 students from four disciplines (medicine, nursing, pharmacist and public health), 22 faculty members as IPE tutors, 20 community members as SP's and 25 real patients who suffered or had history of chronic disease (s). Students were recruited as volunteers divided into 20 groups. Program was delivered from March to October 2012.

\section{Data Collection}

Quantitative data. The self-reported of GA and IC scales were collected at after simulation activity (T1), after first patient visit (T2), and after second patient visit (T3) and time period between T1, T2 and T3 were a month. The first survey was distributed to all participants and returned after simulation sessions were finished. The second survey was given after all groups conducted a discussion in first patient visit and the last survey was carried out after discussion in second patient visit. Collection data of group performance was employed with multiple observations by a tutor team during both simulation activity and first patient visit by using check-list form. The criteria of evaluation of group performance were team function ( 7 items), communication skills in team (6 items), and ability to cooperate with other professions (4 items).

Qualitative data. This data were collected after third patient visit. Students filled in the open-ended questionnaire about (1) what barriers did students find in the program, (2) what the factors caused conflict in team, (3) did students agree if this activity was integrated into the curriculum.

\section{Data Analysis}

Quantitative analysis. Repeated measure analysis of variance (RM-ANOVA) was used to analyze the data of GA and IC scales, where the main factors were "disciplines" and "time" with the interaction. Bonferroni post hoc test was conducted, when appropriate, to examine the main time factor means between $\mathrm{T} 1 * \mathrm{~T} 2, \mathrm{~T} 1 * \mathrm{~T} 3$ and $\mathrm{T} 2 * \mathrm{~T} 3$.

Qualitative analysis. For each open-ended question, (1) written responses were initially classified for content, (2) a list of themes was generated and (3) all responses were coded using those themes.

\section{Ethical Considerations}

All students, tutors, SP`s and real patients gave written and oral informed consents after receiving both written and oral information about this study. The Ethics Committees of UIN Jakarta had approved the research.

\section{RESULT}

\section{A. Intragroup Conflict (IC)}

Only 62 students have completely finished the program. The proportion of femaleparticipants $(n=47,75.8 \%)$ was higher than male participants. Students who participated in this study were from medicine $(n=14)$, pharmacy $(n=15)$, public health $(\mathrm{n}=16)$, and nursing $(\mathrm{n}=17)$ disciplines. 
TABLE 1. MEAN AND STANDARD DEVIATION OF ITEMS OF GA AND IC SCALE IN THREE PERIODS OF MEASUREMENT

Period of Measurement (Mean-SD)

\begin{tabular}{|c|c|c|c|}
\hline Items & $\mathrm{T} 1$ & $\mathrm{~T} 2$ & $\mathrm{~T} 3$ \\
\hline IC Scale (10 items) & $36.29(7.85)$ & $32.03(6.89)$ & $33.37(8.22)$ \\
\hline $\begin{array}{l}\text { Factor of relationship conflict } \\
\text { (RC) }\end{array}$ & $14.02(3.31)$ & $12.15(3.33)$ & $12.68(3.94)$ \\
\hline $\begin{array}{l}\text { 1. There is a lot of friction } \\
\text { among team members. }\end{array}$ & $4.11(1.12)$ & $3.31(1.08)$ & $3.39(1.19)$ \\
\hline $\begin{array}{l}\text { 2. There are personality } \\
\text { conflicts evident in my } \\
\text { team. }\end{array}$ & $3.44(1.03)$ & $2.90(0.88)$ & $3.16(1.22)$ \\
\hline $\begin{array}{l}\text { 3. There are tensions } \\
\text { among members of my } \\
\text { team. }\end{array}$ & $3.52(1.13)$ & $3.03(0.92)$ & $3.03(1.02)$ \\
\hline $\begin{array}{l}\text { There are emotional } \\
\text { conflicts among } \\
\text { members of my team. }\end{array}$ & $2.95(0.91)$ & $2.90(0.88)$ & $3.10(1.11)$ \\
\hline Factor of task conflict (TC) & $13.90(3.01)$ & $13.37(2.82)$ & $14.58(3.33)$ \\
\hline $\begin{array}{l}\text { 5. Members in my team } \\
\text { disagree about opinions } \\
\text { regarding the work } \\
\text { being done. }\end{array}$ & $3.23(0.97)$ & $3.08(0.89)$ & $2.98(0.93)$ \\
\hline $\begin{array}{l}\text { 6. There are conflicts } \\
\text { about ideas in my team. }\end{array}$ & $3.45(1.04)$ & $3.24(0.95)$ & $3.37(1.00)$ \\
\hline $\begin{array}{l}\text { 7. There is conflict about } \\
\text { the work in my team. }\end{array}$ & $3.55(1.05)$ & $3.08(0.87)$ & $3.19(0.90)$ \\
\hline $\begin{array}{l}\text { Factor of process conflict } \\
\text { (PC) }\end{array}$ & $16.06(4.60)$ & $13.98(3.45)$ & $14.86(4.28)$ \\
\hline $\begin{array}{l}\text { 8. There are disagreements } \\
\text { about who should do } \\
\text { what in my team. }\end{array}$ & $4.13(1.24)$ & $3.60(1.06)$ & $3.90(1.20)$ \\
\hline $\begin{array}{l}\text { 9. There is conflict about } \\
\text { task responsibilities in } \\
\text { my team. }\end{array}$ & $3.94(1.29)$ & $3.32(0.92)$ & $3.48(1.17)$ \\
\hline $\begin{array}{l}\text { 10. There is disagreement } \\
\text { about resource } \\
\text { allocation in my team. }\end{array}$ & $3.98(1.18)$ & $3.56(1.05)$ & $3.76(1.22)$ \\
\hline
\end{tabular}

Table 1 showed mean score of each items at three period of measurement. The mean-score of items of IC scale ranged from 2.90 to 4.13 (response from "strongly disagree" to "neutral") and total mean score was from 32.03 (T2) to 36.29 (T1) and Fig. 1 showed the pattern of three IC sub-scales (RC, TC, PC) over time that varied by professions.

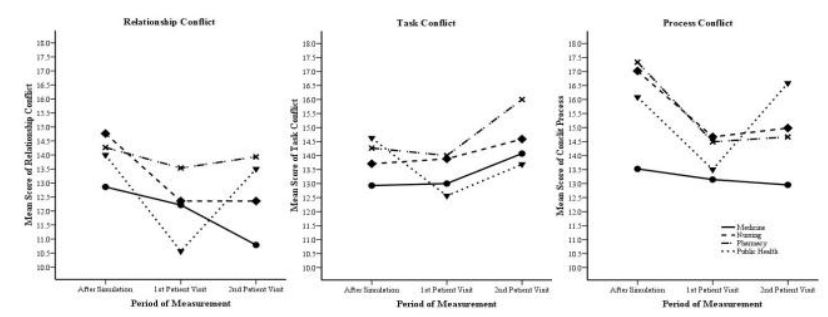

Fig. 1. The patterns of three IC sub-scales in three periods of measurement

Test of RM-ANOVAs of IC scale and the three IC subscales was summarized in Table 2. There was statistically significant effects in IC score for time $(p=0.006)$ but there were not significant effects in IC score for the discipline*time interaction $(\mathrm{F}=0.78$, d.f. $=6, \mathrm{p}=0.591)$. The difference mean score between Time 2 and Time 3 was statistically significant $(\mathrm{p}=0.002)$ but insignificant result was detected between Time 1 and Time $2(\mathrm{p}=0.776)$ and Time 1 and Time $3(\mathrm{p}=0.110)$.

TABLE 2. SUMMARY OF GA AND IC SCALES OF REPEATED MEASURED ANOVA

\begin{tabular}{|c|c|c|c|c|c|c|c|}
\hline \multirow[t]{2}{*}{ Instrument } & \multicolumn{3}{|c|}{$\begin{array}{c}\text { Period of Measurement } \\
(\text { Mean-SD) }\end{array}$} & \multicolumn{2}{|c|}{ Time factor } & \multicolumn{2}{|c|}{$\begin{array}{l}\text { Disciplines } \mathrm{x} \\
\text { Time } \\
\end{array}$} \\
\hline & T1xT2 & T1xT3 & T2xT3 & $\mathrm{P}$ & ES & $\mathrm{p}$ & ES \\
\hline IC sub-scale & 0.776 & 0.110 & 0.002 & 0.006 & 0.089 & 0.591 & 0.041 \\
\hline $\mathrm{RC}$ & 0.005 & 0.098 & 1.000 & 0.006 & 0.088 & 0.273 & 0.065 \\
\hline $\mathrm{TC}$ & 1.000 & 0.169 & 0.051 & 0.058 & 0.051 & 0.821 & 0.026 \\
\hline $\mathrm{PC}$ & 0.011 & 0.533 & 0.437 & 0.045 & 0.057 & 0.584 & 0.040 \\
\hline $\begin{array}{l}\text { GA sub- } \\
\text { scale }\end{array}$ & 0.743 & 1.000 & 0.232 & 0.179 & 0.031 & 0.648 & 0.037 \\
\hline TR & 1.000 & 0.832 & 0.923 & 0.443 & 0.015 & 0.938 & 0.016 \\
\hline RO & 0.199 & 1.000 & 0.137 & 0.680 & 0.048 & 0.688 & 0.034 \\
\hline OD & 0.387 & 1.000 & 0.230 & 0.130 & 0.036 & 0.312 & 0.061 \\
\hline
\end{tabular}

Similarly, the assumption of sphericity was not violated by Mauchly's Test for those three IC sub-scales. There were statistically effects in RC sub-scale $(\mathrm{p}=0.005)$ and PC subscale $(p=0.011)$ over time. The difference mean score between Time 1 and Time 2 were statistically significant on RC subscale $(\mathrm{p}=0.006)$ and $\mathrm{PC}$ sub-scale $(\mathrm{p}=0.045)$. The effect size on mean score of IC scale and three IC sub-scales due to time and discipline*time interaction was a small effect $(\eta<0.3)$.

\section{B. Group Atmosphere (GA) Scale}

In Table 3, the mean score of each items ranged from 5.10 to 5.60 (response from "agree" to "strongly agree") and the total mean score stretched from 41.81 (T2) to 43.11 (T1).

TABLE 3. MEAN AND STANDARD DEVIATION OF ITEMS OF GA AND IC SCALE IN THREE PERIODS OF MEASUREMENT

\begin{tabular}{|c|c|c|c|}
\hline \multirow[b]{2}{*}{ Items } & \multicolumn{3}{|c|}{$\begin{array}{l}\text { Period of Measurement } \\
\text { (Mean - SD) }\end{array}$} \\
\hline & $\mathrm{T} 1$ & $\mathrm{~T} 2$ & $\mathrm{~T} 3$ \\
\hline \multirow[t]{3}{*}{ GA Scale (8 items) } & 43.11 & 41.81 & 42.79 \\
\hline & $(5.04)$ & (3.87) & $(5.13)$ \\
\hline & 15.65 & 15.60 & 15.79 \\
\hline Factor of trust (TR) & $(1.93)$ & $(1.45)$ & $(2.12)$ \\
\hline 1. Members in my team trust & 5.26 & 5.24 & 5.23 \\
\hline each other. & $(0.79)$ & $(0.50)$ & $(0.78)$ \\
\hline \multirow{2}{*}{$\begin{array}{l}\text { Members in my team feel } \\
\text { comfortable delegating to } \\
\text { others in the team. }\end{array}$} & 5.13 & 5.10 & 5.13 \\
\hline & $(0.82)$ & $(0.62)$ & $(0.76)$ \\
\hline \multirow{3}{*}{$\begin{array}{l}\text { Team members are } \\
\text { and honest. }\end{array}$} & 5.26 & 5.26 & 5.44 \\
\hline & $(0.72)$ & $(0.51)$ & $(0.84)$ \\
\hline & 16.69 & 15.90 & 16.45 \\
\hline Factor of respect each other (RO) & $(2.34)$ & $(1.59)$ & $(2.17)$ \\
\hline 4. Team members respect each & 5.60 & 5.27 & 5.50 \\
\hline other. & $(0.80)$ & $(0.55)$ & $(0.76)$ \\
\hline Team members respect each & 5.53 & 5.32 & 5.47 \\
\hline others' ideas. & $(0.86)$ & $(0.54)$ & $(0.74)$ \\
\hline & 16.34 & 15.61 & 16.03 \\
\hline Factor of open discussion (OD) & $(2.09)$ & $(1.74)$ & $(2.13)$ \\
\hline 6. In my team, we discuss & 5.52 & 5.31 & 5.37 \\
\hline issues openly. & $(0.78)$ & $(0.56)$ & $(0.75)$ \\
\hline \multirow{2}{*}{$\begin{array}{l}\text { In my team, we } \\
\text { communicate op }\end{array}$} & 5.50 & 5.26 & 5.44 \\
\hline & $(0.70)$ & $(0.54)$ & $(0.84)$ \\
\hline \multirow{2}{*}{ dealt with openly. } & 5.32 & 5.05 & 5.23 \\
\hline & $(0.86)$ & $(0.86)$ & $(0.73)$ \\
\hline
\end{tabular}


Fig. 2 showed the pattern of GA over time and the mean score of medical group was increased gradually across time on all sub-scales.
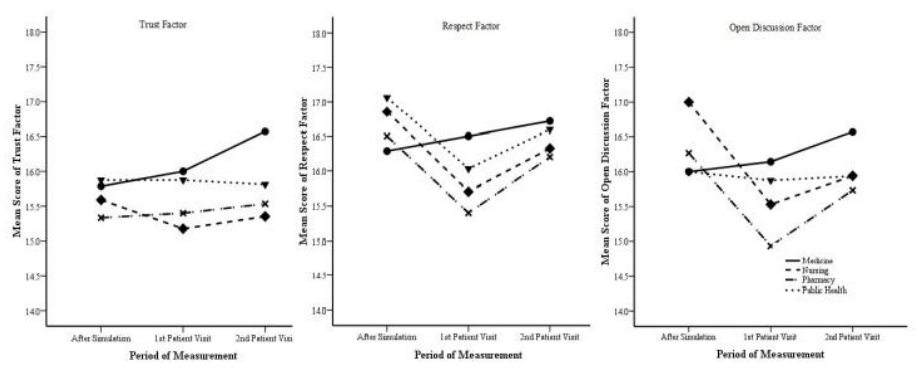

Fig. 2 The patterns of three GA sub-scales in three periods of measurement

Test of RM-ANOVAs of GA scale and three GA sub-scales were summarized in Table 2 and there were not violations to the assumption of sphericity. There were not statistically significant effects of mean score for time and discipline*time interaction on GA scale and three GA sub-scales.

\section{Student Writen Comments}

Written comments showed that $89.8 \%$ of students agreed that the program was integrated into the curriculum. The factors that caused conflict in the group are summarized in Fig. 3. They commented on conflict such as "it was difficult to set up the schedule for discussions with group members ... the schedules between disciplines was not fit." Their comment about the overlapping tsk or responsibilities among disciplines such as "only for the first time when we come together, I felt the overlapping of knowledge among disciplines, but after being involved in teamwork during this activity, we're getting used to it." In their written comments about the relationship with other members, the participant described about the difficulty to have a certain attitude toward and communicate with other professions. The participant wrote that "... hesitant how to behave in a team and communicate with other group members."

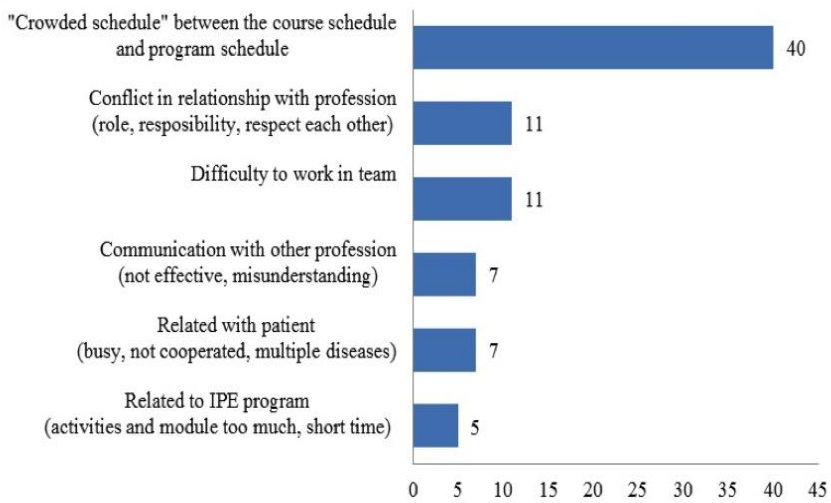

Fig. 3. Student's responses about the factors as triggers of intragroup conflict

\section{DISCUSSION}

The COMIC program is an initiative model of interprofessional learning in Indonesia The data analysis demonstrated an overview of pattern of conflict types and group process and statistical significant impact on the improvement of intragroup conflict across time and group performance.

In this study, the pattern on intragroup conflict and development of group process varied among professions. The program yielded a satisfactory result, and opted only one method in IP program will not be effective to achieve the IP objectives due to be difficult to respond to the diverse needs of students [8].

There are several factors affected interprofessional team conflict. First, the background of education systems. Both medical and public health students showed the uniqueness of graph pattern. The patterns of intagroup conflict and group process of medical students, except the pattern of TC, were different from other disciplines, which the mean score of IC scale tend to decreased and GA scale increased gradually across time. It indicated that medical students were accustomed to work in teams attributable to the medical program implemented problem based learning (PBL) since the first year, while the other disciplines applied lecture-based learning in large classroom. This evidence supported previous studies that the ability to cooperate formed through a continual process and PBL had developed students' ability to resolve conflicts within the team, developing a good group process, and better to adapt on different professional behavior in an interprofessional team [16].

Similarly, the pattern of conflict types among public health students tend dramatically to decrease and increase over time that related to the activities in this program. During the phase of simulation activity and third patient visit, each group conducted group discussion to manage patient problem. In this situation, public health students proposed disease prevention and health promotion as main strategy to solve patient problem whereas other disciplines were more likely to treat patient illness. A difference in educational background has been a trigger of professional conflict that influent in the development group and other conflicts. This conflict also was known as the professional conflict [5].

Second, workload in group. In this study, task conflict had a tendency to increase over time and this result was relevance with the previous study $[17,10]$. In this study, increasing the TC and PC, were associated with the group task to manage patients because managing a patient in primary care service by an interprofessional team need a holistic management care $[18,19]$ that focus on curative, prevention and bio-psycho social approach. The group however needed the experiences and complex skills to handle several group tasks at once and this condition sparked the task conflict in team $[3,20]$.In addition, workloads in this group were also exacerbated by the fact that working with real patient in primary care was the first experience for all participants.

Third, overlapping of knowledge and competencies played role to emerge the PC [5]. When conducting group discussion and patient visit, the participants deal with the overlapping some competencies. In interprofessional health teams, 
overlapping the competencies will be linked to the responsibility and authority to manage patients. If the rule of professional responsibilities were blurred then this condition will lead to conflict [5]. Nevertheless, the participants stated that they were able to handle this situation by constantly interacting in teamwork with other group members so that each group member comprehended and capable to overcome this problem. Those result reflected that the conflict related to overlapping task and responsibility were a sensitive conflict in health team and this is a challenge why the development of teamwork in medical and health groups seem less developed than on non-health field [21].

Fourth, inability to communicate with other profession was also as a trigger of process conflict in group [22]. Although the simulation activities trained all participants how to communicate with group members, but apparently not enough to form the ability to put into practice with a real patient. It is not surprisingly because the communication module that mainly taught to students over the years were the communication to the patient and communication with own profession. Communication with different profession in either simulation or real setting was rare taught and trained to the students [5].

This study provided valuable evidence of the development of intragroup conflict in interprofessional learning process and showed how norms and social process influenced the group development. However, this study is not specified whether the norm and social process stimulate or inhibit group development [5].

Despite its finding, the study has limitations. Firstly, many students were withdrawn from this activity. In the future, to reduce the drop-out rate, IPL program could be made a mandatory part of the curriculum. Secondly, this study only had short time to observe student groups within the three months. With more longer observation, therefore, both intragroup conflict and group performance might be shown comprehensive result.

\section{CONCLUSION}

Conflict will arise in a teamwork. However, handling the factors that have the potential for conflict in interprofessional learning can be overcome by developing an integrated educational program and therefore improve group performance, student's ability and quality of care.

\section{ACKNOWLEDGMENT}

We would like to thank all students, volunteer people, patients and family members as well as faculty and hospital staffs who participated in this study.

\section{DECLARATION OF INTEREST}

The University of Tokyo and The State Islamic University Syarif Hidayatullah provided funding for this study. The authors report no conflict of interest. The authors alone are responsible for the writing and content of this paper.

\section{REFERENCES}

[1] K. A. Jehn and C. Bendersky, "Intragroup Conflict in Organizations: A Contingency Perspective on the Conflict-outcome Relationship," Research in Organizational Behavior, vol. 25, pp. 187-242, 2003.

[2] J. Wall and R. Callistar, "Conflict and its Management," Journal of Management, vol. 21, pp. 515-558, 1995.

[3] C. K. De Dreu and L. R. Weingart, "Task Versus Relationship Conflict, Team Performance, and Team Member Satisfaction: A Meta-Analysis," Journal of Applied Psychology, vol. 88, no. 4, pp. 741-749, 2003.

[4] J. O. Billups, "Interprofessional team process," Theory into practice, vol. 2, pp. 146-152, 1987.

[5] P. Hall, "Interprofessional teamwork: Professional cultures as barriers," Journal of Interprofessional Care, pp. 188-196, May 2005.

[6] H. Barr, "Interprofessional education : Today, yesterday and tomorrow," Learning and Teaching support Network: Centre for Health Sciences and Practice, 2002.

[7] P. Van den Bossche, W. H. Gijselaers, M. Segers and P. A. Kirschner, "Social and Cognitive Factors Driving Teamwork in Collaborative Learning Environments: Team Learning Beliefs and Behaviours," Small Group Research, vol. 27, no. 5, pp. 490-521, October 2006.

[8] H. Barr, I. Koppel, S. Reeves and M. Ham, Effective Interprofessional Education: Argument, Assumption and Evidence (Promoting Partnership for Health) Hugh Barr, Ivan Koppel, Scott Reeves, Marilyn Hammick, Della S. Freeth August 2005, Wiley-Blackwell, Oxford: Blackwell Publishing, 2005.

[9] B. Tuckman and N. Jensen, "Stages of small group development revisited," Group and Organization Studies, vol. 12, pp. 419-421, 1977.

[10] K. A. Jehn and E. A. Mannix, "The Dynamic Nature of Conflict: A Longitudinal Study of Intragroup Conflict and Group Performance," The Academy of Management Journal, vol. 44, no. 2, pp. 238-251, 2001.

[11] J. Abarca, A. Bedard and D. Carlson, "Chapter 6: Teamwork and Working in Team," in Introductory Engineering Design: A ProjectBased Approach, Colorado, The University of Colorado, 2000, pp. 3954.

[12] K. A. Jehn, "A multimethod examination of the benefits and detriments of intragroup conflict," Administrative Science Quarterly, vol. 40, no. 2 , pp. 256-282, June 1995.

[13] J. Chatman, "Matching people and organizations: Selection and socialization in public accounting firms.," Adminstrative Science Quarterly, vol. 36, pp. 459-484, 1991.

[14] P. P. Shah and K. A. Jehn, "The Interaction of Friendship, Conflict, and Task," Group Decision and Negotiation, vol. 2, pp. 149-165, 1993.

[15] F. Guillemin, C. Bombardier and D. Beaton, "Cross-cultural adaptation of health-related quality of life measures: literature review and proposed guidelines," J Clin Epidemiol, vol. 46, no. 12, pp. 1417-1432, 1993.

[16] H. Lin, Y. Lin, T. Chan, C. Lai, C. Chin and F. Chou, "The impact of an interprofessional problem-based learning curriculum of clinical ethics on medical and nursing students' attitudes and ability of interprofessional collaboration: A pilot study," Kaohsiung J Med Sci., vol. 29, no. 9, pp. 505-511, September 2013.

[17] C. Gersick, "Time and transitions in work teams:Toward a new model of group development," Academy of Management Journal, vol. 3, pp. 9-41, 1988.

[18] T. Virani, "Interprofessional Collaborative Teams," Canadian Health Services Faoundation, Ottawa, Ontario, 2012

[19] M. Clifton, C. Dale and C. Bradshaw, "The Impact and Effectiveness of Inter-professional Education in Primary Care: A RCN Literature Review," Royal College of Nursing, London, 2006.

[20] K. J. Behfar, E. A. Mannix, R. S. Peterson and M. William, "Conflict in Small Groups: The Meaning and Consequences of Process Conflict," Small Group Research, vol. 42, pp. 127-176, 2011.

[21] P. Solomon and C. Risdon, "Promoting interprofessional learning with medical students in home care setting," Medical Teacher, vol. 33, pp. e236-e241, 2011. 
[22] P. Marshall and R. Robson, "Preventing and Managing Conflict: Vital Pieces in the Patient Safety Puzzle," Healthcare Quarterly, vol. 8, pp. 39-44, October 2005

[23] J. F. Hair, Multivariate Data Analysis, 6th ed., Upper Saddle River, NJ: Prentice Hall, 2005.

[24] S. Mickan and S. Rodger, "Characteristics of effective teams: a literature review," Australian Health Review, vol. 23, no. 3, pp. 201-208, 2000

[25] D. Harrington, Confirmatory factor analysis, New York, NY: Oxford University Press, 2009.

[26] S. Ponzer, U. Hylin, A. Kusoffsky and M. Lauffs, "Interprofessional training in the context of clinical practice: goals and students' perceptions on clinical education wards," Medical Education, vol. 38, no. 7, pp. 727$736,2004$.
[27] P. Bayerl, "Co-Learning in Health Care: Evaluation of the Interprofessional Training Program at the Bedlam Longitudinal Clinic," 2008. [Online]. Available:

http://tulsa.ou.edu/bedlam/pdf/Capstone psbayerl final.pdf. [Accessed 19 November 2010].

[28] G. Johansson, K. Eklund and G. Gosman-Hedström, "Multidisciplinary team, working with elderly persons living in the community: a systematic literature review," Scand J Occup Ther, vol. 17, no. 2, pp. 101-116, 2010.

[29] H. Barr, M. Helme and L. D'Avray, "Developing Interprofessional Education in health and social care courses in the United Kingdom: A Progress Report," Higher Education Academy, Health Sciences and Practice Subject Centre, London, 2011. 